\title{
The Life of Lichen ${ }^{1}$
}

\section{James Stevenson, Lara B. Milligan, and Jennifer L. Gillett-Kaufman²}

Florida is home to a vast diversity of an amazing group of organisms called lichens. What are these organisms? They are neither a plant nor an animal, but they are living, breathing, reproducing, and complex organisms, the result of a seemingly impossible relationship.

There is a saying that goes: "Freddie Fungus and Alice Alga took a lichen for each other," but it is a bit more complicated than two different organisms, a fungus and an alga, coexisting. Lichens are composed of several organisms from three different kingdoms: fungi, plants, and bacteria.

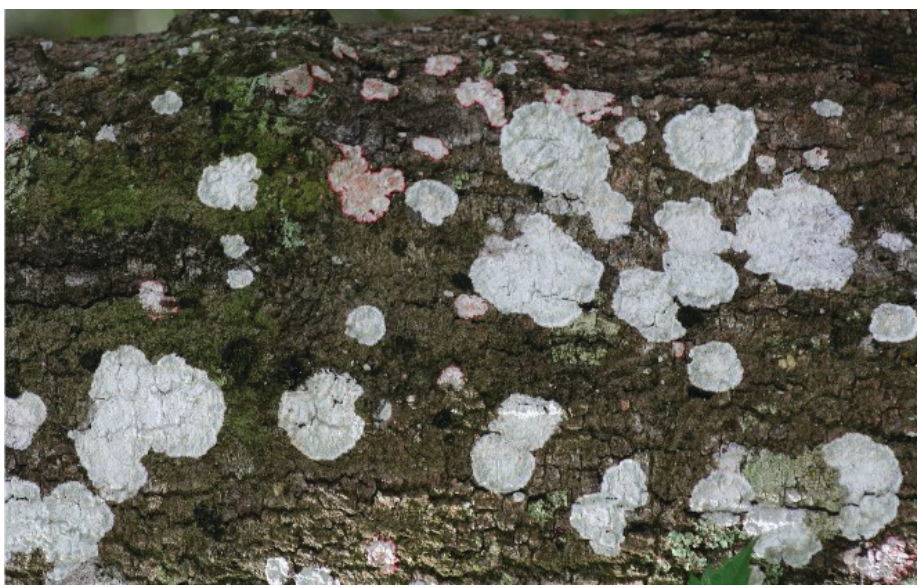

Figure 1. Tree trunk with many lichen species.

Credits: J. Stevenson, UF/IFAS

The association of these separate organisms is often referred to as a mutualistic relationship, defined as two or more organisms living in a mutually beneficial arrangement. An example would be the clownfish that lives amongst the tentacles of a sea anemone. The brightly colored clownfish acts as a lure that draws other fish into the deadly tentacles. The clownfish's immunity to the anemone's toxin allows it a safe place to live while feeding on scraps of food left over from the anemone. The anemone gets the advantage of a live-in fish lure.

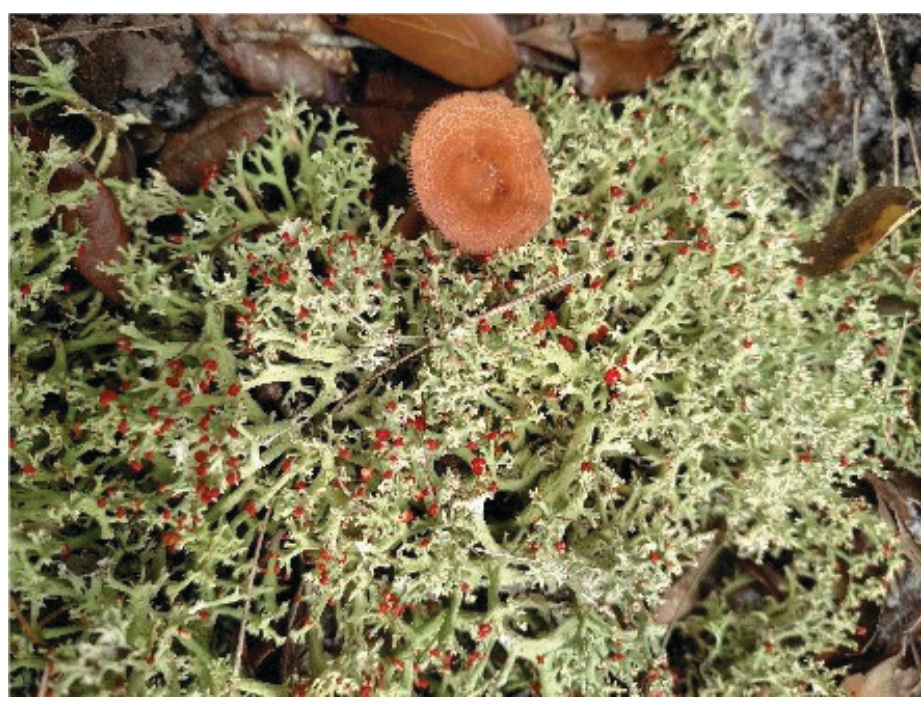

Figure 2. Jester lichen (Cladonia leporina).

Credits: J. Stevenson, UF/IFAS

Lichens are a bit different. The algal component of a lichen can survive outside of the relationship, while the fungal component cannot. Therefore, rather than a mutually beneficial relationship, there are signs that the fungus is actually taking nutrients away from the alga, or parasitizing its host.

1. This document is ENY-2051, one of a series of the Entomology and Nematology Department, UF/IFAS Extension. Original publication date November 2020. Visit the EDIS website at https://edis.ifas.ufl.edu for the currently supported version of this publication.

2. James Stevenson, Extension program assistant, UF/IFAS Extension Pinellas County; Lara B. Milligan, natural resources Extension agent, UF/IFAS Extension Pinellas County; and Jennifer L. Gillett-Kaufman, former Extension scientist, Entomology and Nematology Department; UF/IFAS Extension, Gainesville, FL 32611.

The Institute of Food and Agricultural Sciences (IFAS) is an Equal Opportunity Institution authorized to provide research, educational information and other services only to individuals and institutions that function with non-discrimination with respect to race, creed, color, religion, age, disability, sex, sexual orientation, marital status, national origin, political opinions or affiliations. For more information on obtaining other UF/IFAS Extension publications, contact your county's UF/IFAS Extension office. U.S. Department of Agriculture, UF/IFAS Extension Service, University of Florida, IFAS, Florida A \& M University Cooperative Extension Program, and Boards of County Commissioners Cooperating. Nick T. Place, dean for UF/IFAS Extension. 


\section{Lichen Biology}

\section{Fungi}

The fungal component, or mycobiont, provides the structure of the lichen and feeds off the sugars produced by the alga/bacteria component, the photobiont(s). The most common fungi present in lichen associations belong to the Ascomycetes, or cup fungi. These produce cup-shaped structures called ascocarps (Figures 3 and 4) which contain spore-producing cells. When spores are released, they grow into the next generation of cup fungi. The capacity of this group of fungi to express this cup-shaped structure is maintained in lichen associations. You can often find lichen with these growths as an expression of one type of lichen reproduction (Figure 4). For a long time, scientists studying lichen associations could not understand how the same combinations of myco- and photobionts could lead to entirely different lichen organisms. Recently an additional element has been discovered to exist within this arrangement: yeast. Yeasts are single-celled members of many groups of fungi, including, but not limited to, the Ascomycetes. These fungi were not considered to be a part of lichen traditionally. It has recently been proven that yeast plays an essential role in forming many lichen species. This realization explains why the same species of lichen cannot be created in the lab by combining known fungal/algal components without the presence of the yeast.

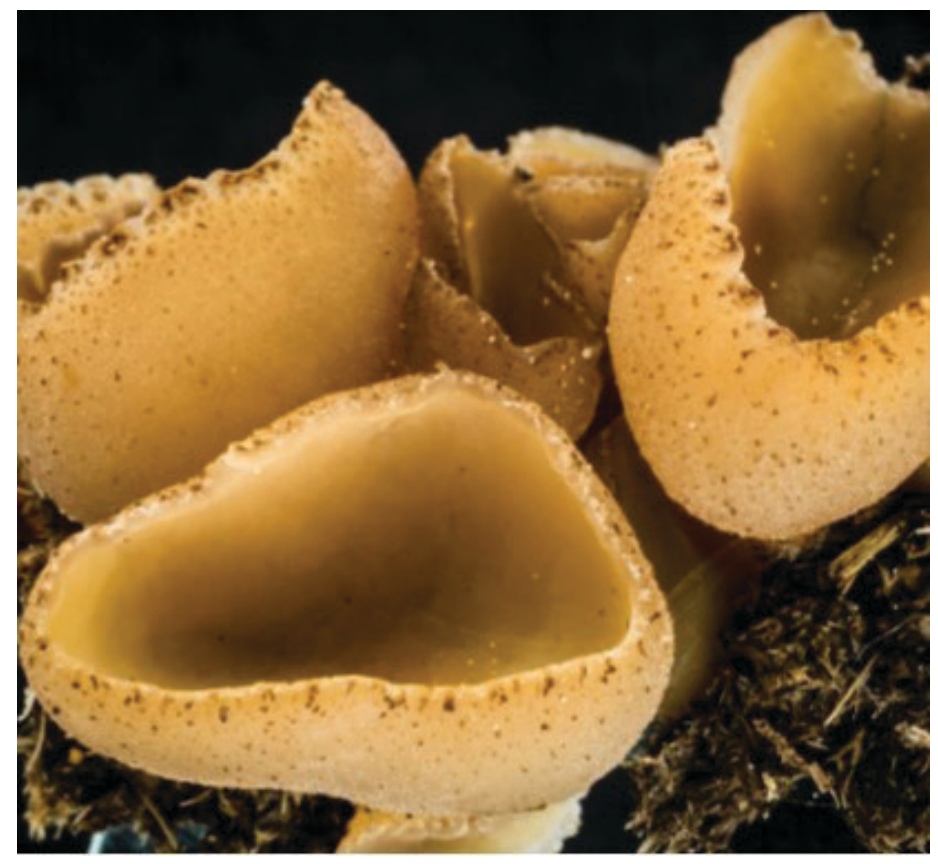

Figure 3. Typical cup fungus, or Ascomycete. Credits: Sava Krstic

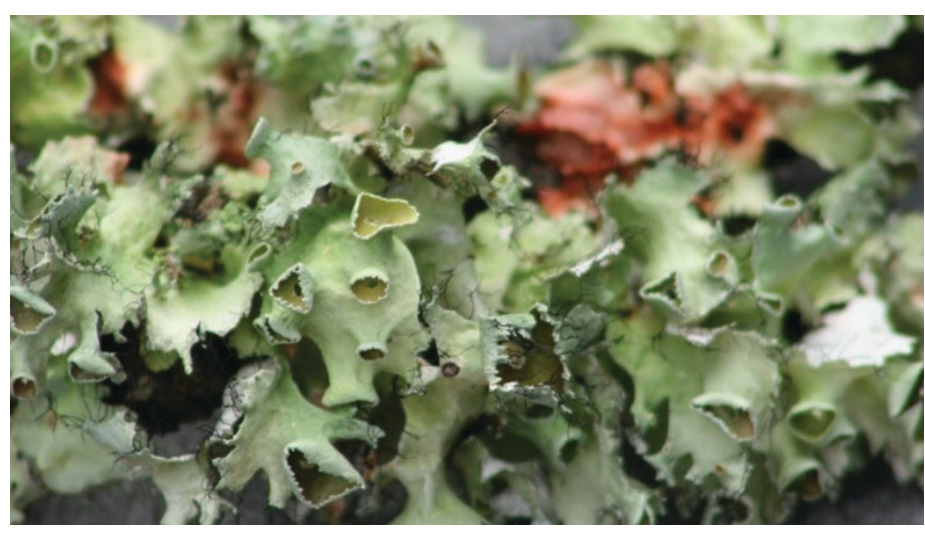

Figure 4. Well-developed ascocarps on a shield lichen (Parmelia sp.). Credits: J. Stevenson, UF/IFAS

\section{Plants}

As for the photobionts, we will examine the algae first. One genus often assimilated into a lichen association is Trebouxia spp. (Figure 5).

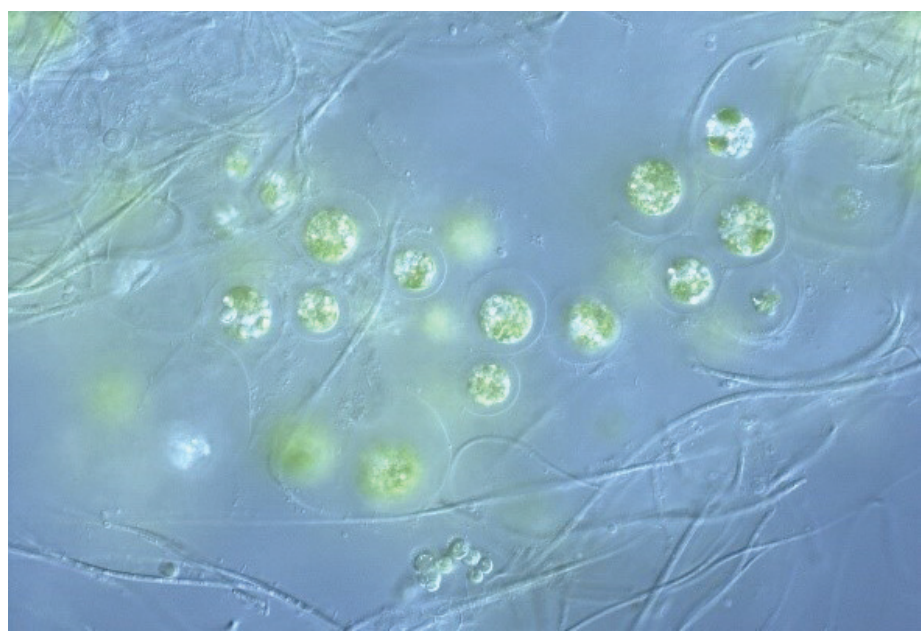

Figure 5. Trebouxia sp., an alga often found in lichen associations. Credits: Kyle Fontaine

This single-celled alga is in the Chlorophyta or green algae group of the plant kingdom. Trebouxia can exist as a freeliving alga, found on the surface of the soil, on tree trunks, and on fence posts. Another green alga, Trentepohlia is often found in lichen associations. This genus is terrestrial and can be found in the same habitats as Trebouxia, though in the Tropics it is found growing on the surface of plant leaves. Despite being a green alga, Trentepohlia has other pigments besides chlorophyll that often give it an orange or yellow appearance.

\section{Bacteria}

Another of the lichen photobiont groups are cyanobacteria, formerly known as blue-green algae. These are true bacteria, neither plant nor fungus. One of these, Nostoc, exists as a chain of bead-like cells, including special cells called heterocysts that have the capacity to fix atmospheric nitrogen into a form that is available to the photosynthetic 
cells. Free-living Nostoc can be found on the surface of the soil as a gelatinous green mass, often after a rain event. Nostoc may also exist as aquatic gelatinous masses in slow-moving water.

\section{Fungus depends on the photobiont(s) for survival}

The evolution of lichens has resulted in the inability of the fungal species in a lichen association to exist as a free-living organism. Even under perfect laboratory conditions, the fungus when isolated out of a lichen cannot survive for an extended period of time. The algae and bacteria, however can and do exist as free-living organisms.

\section{Lichen Reproduction}

Lichen reproduce primarily asexually by creating microscopic bundles (soredia, Figure 6) of all components (fungus, plant, and bacteria) that make up the lichen species and releasing them into the air. If these soredia land on a suitable habitat in which to grow, they will begin the process of creating the body (thallus) of the lichen in the same arrangement as the parent lichen.

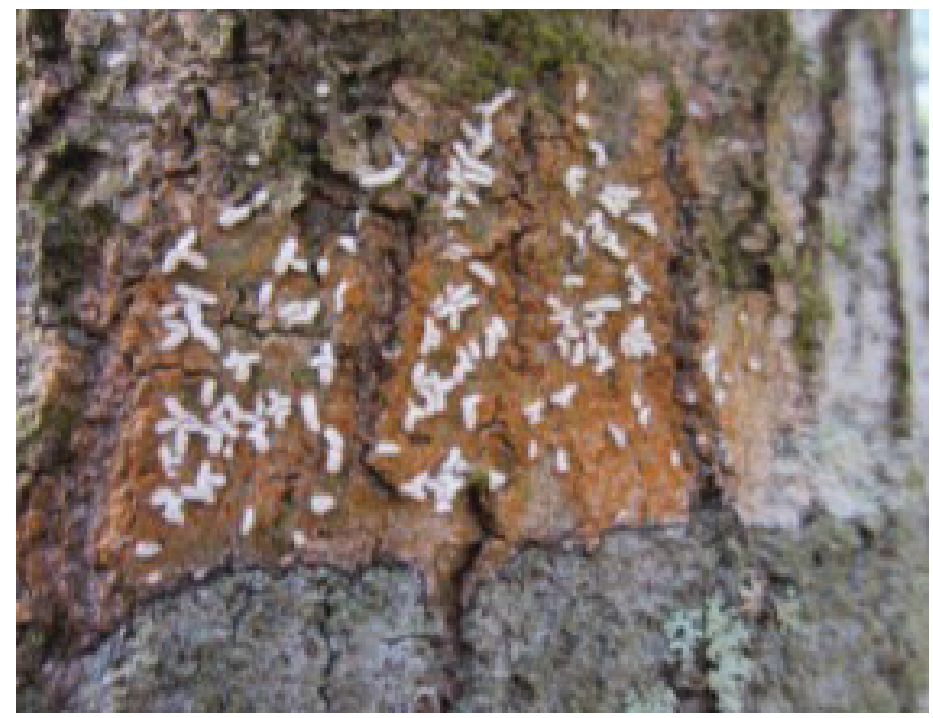

Figure 6. The white areas of this "script" lichen are releasing soredia. Credits: J. Stevenson, UF/IFAS

Similar to soredia, isidia are outgrowths of the surface of the thallus and contain each component of the parent lichen in microscopic bundles. When they break free of the surface and land on a suitable growing surface, each component begins to grow into a clone of the parent lichen.

Sexual reproduction of lichens has not been observed in the lab, but for lichens to exist at all, and for the continued diversification, this must have occurred many times and must continue to happen today. The fungal component does produce viable fungal spores, often in cup-shaped structures (Figure 4). However, to form a new lichen from these spores, they would have to germinate in the presence of the other wild-living components of the lichen species.

\section{The Structure (Thallus) of a Lichen}

The basic structure of a lichen is like that of the popular peanut butter cup candy. A layer of photobionts (the peanut butter) is held within a matrix of fungal fibers or hyphae (the chocolate). This allows the photobionts access to sunlight as well as protection from drying out. The protective role of the fungus has allowed lichens to inhabit extreme environmental conditions and is one reason they can be found on every continent. Lichen can be found living on rock surfaces in harsh climates that would prove lethal to the photobionts on their own. Even more impressive, lichens have been observed performing photosynthesis while frozen at $-20^{\circ} \mathrm{C}$ !

\section{Lichen Diversity}

There is no global list of known lichen species, but estimates vary from 13,000 to 30,000 different species. The various growth forms are described as crustose, foliose, and fruticose.

\section{Crustose}

Crustose lichens are those that exist as if painted onto the surface they grow on. It is nearly impossible to pry the organism from the surface. Examples of crustose lichens include the very colorful Baton Rouge lichen, Cryptothecia rubrocincta (also referred to as Herpothallon rubrocinctum) (Figure 7).

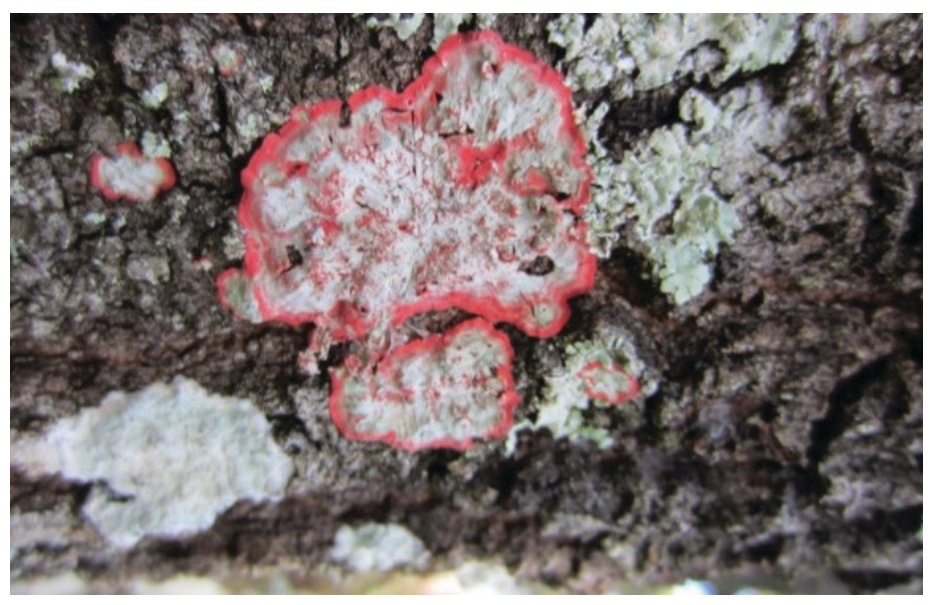

Figure 7. Crustose baton rouge (Cryptothecia rubrocincta). Credits: J. Stevenson, UF/IFAS

This lichen exists throughout the southeastern United States and appears as deep-pink circular masses on the trunks of trees. Another interesting group of crustose lichen are 
called the script lichens. The body or thallus of these lichens is marked with scribbles in areas where reproductive structures form. These lichens are found on stones and smooth-barked trees, like red maple, Acer rubrum.

\section{Foliose}

Foliose lichens are leafy with thalli (plural of thallus) that can be folded up and off the surface where they grow.

Parmelia, or shield lichen, is a common genus with a foliose growth habit (Figure 8). These large and easily observed species can be found in a variety of habitats. Their abundance has led to their being used to monitor lichen growth rates as well as air quality. Different species of lichen have different tolerances to air pollutants.

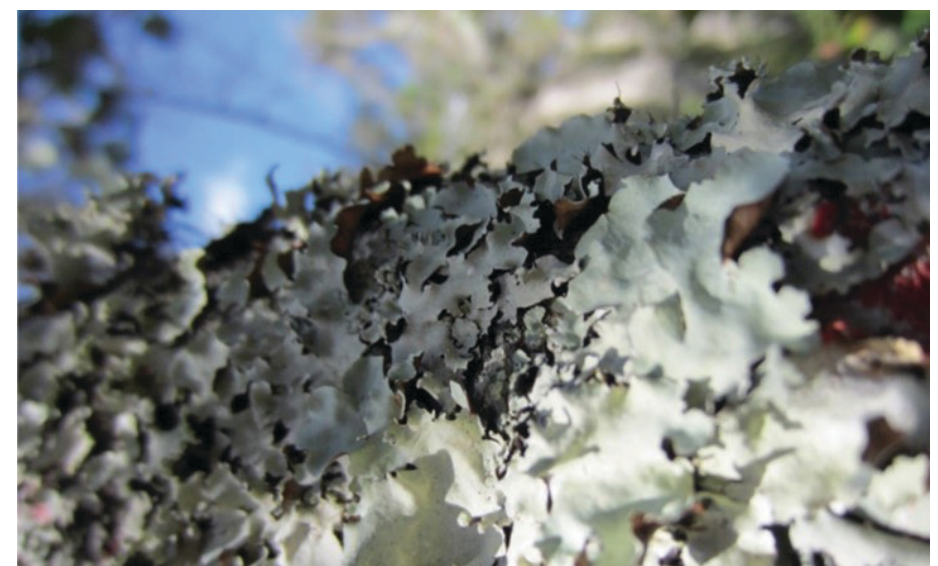

Figure 8. Foliose shield lichen (Parmelia sp.).

Credits: J. Stevenson, UF/IFAS

\section{Fruticose}

Fruticose lichens are shrubby and typically elevated from the substrate on which they grow. Terrestrial examples include a species of Cladonia called deer moss (Figure 9) and jester lichen, Cladonia leporina (Figure 2). These two are abundant in Florida's oak hammock and pine flatwood habitats, though they are not fire-adapted, and colonies may be totally lost following a wildfire. Usnea is another fruticose lichen most often found growing on the trunks and branches of trees in Florida. The genus name translates to "beard" in Latin, and these multi-filamentous lichens may appear as little beards hanging from tree branches, especially after a rain. A charming fruticose lichen called British soldiers or match-stick lichen is another Cladonia species. During its reproductive phase this stick-like lichen bears masses of reproductive structures on the tips that are bright red, like a British soldier's red hat.

\section{Lichen Medicine}

Lichen's ability to synthesize complex compounds for survival/self-defense has led researchers to explore lichen as a source of potential medicinals. There is much more to learn about lichen regarding their ecological role(s), economic importance and traditional uses around the world. This is a budding science; see Rancovic (2015) for more on this fascinating subject.

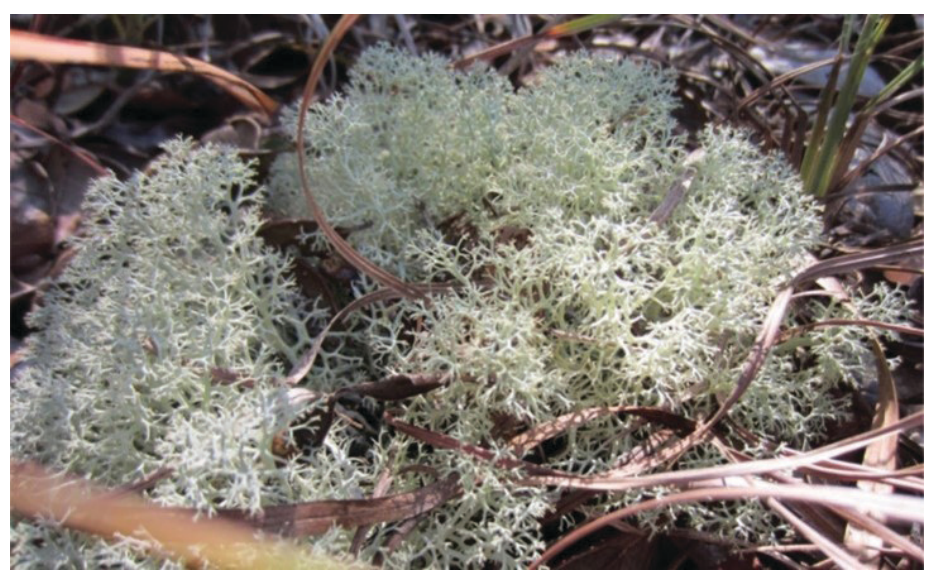

Figure 9. Fruticose, terrestrial deer moss (Cladonia sp.).

Credits: J. Stevenson, UF/IFAS

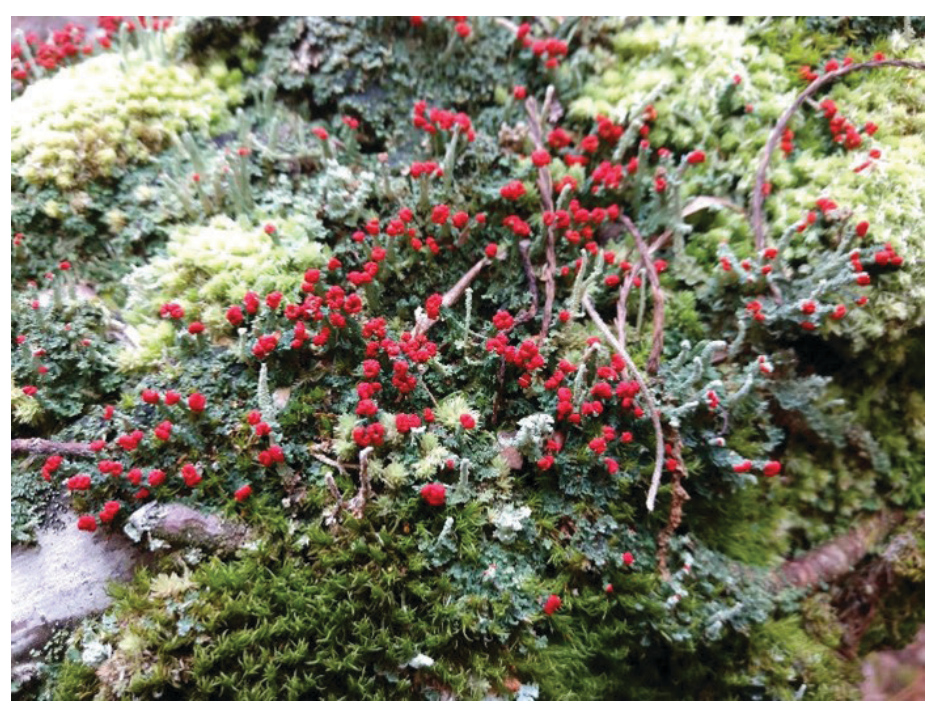

Figure 10. Fruticose, epiphytic British soldiers (Cladonia sp.). Credits: J. Stevenson, UF/IFAS

\section{Lichen and Insects}

Lichen are so common in our environment that many insects have evolved color patterns that mimic lichens to help the insects avoid detection. For example, the grizzled mantid, Gonatista grisea (Figure 11), has developed a color pattern that mimics lichens, allowing it to easily hide undetected on lichen-covered tree trunks while awaiting unsuspecting prey. There are several species of moths in the genus Hypoprepia whose caterpillars feed on lichen, and some members of the genus appear to have lichenpatterned wings as adults. Many species of sphinx moths have lichen patterns on their wings, which helps these moths avoid detection from predators (Figure 12). 


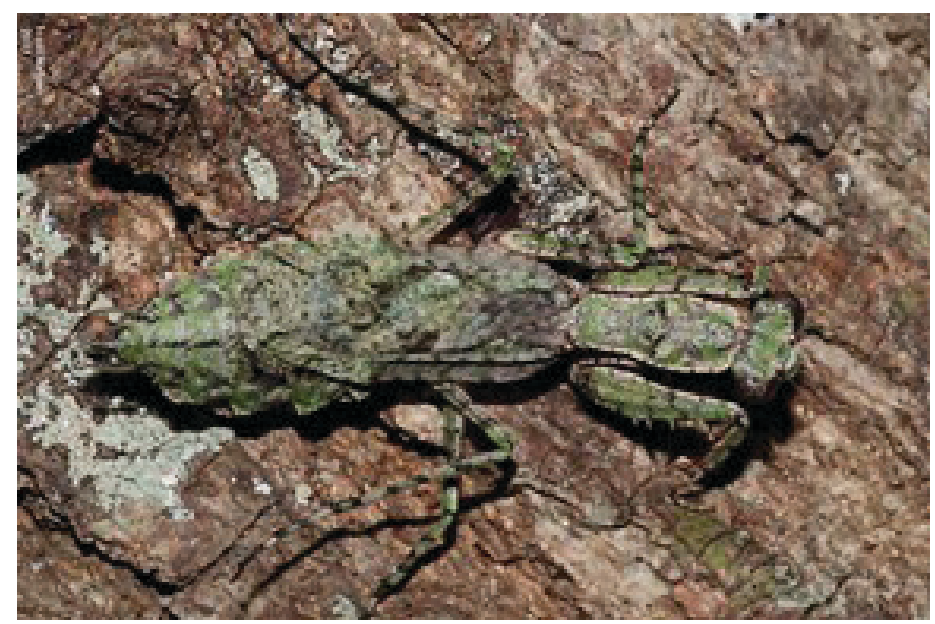

Figure 11. Adult Gonatista grisea, grizzled mantid, on a tree trunk. Credits: Scott D. Nelson, Lutheran School Educator

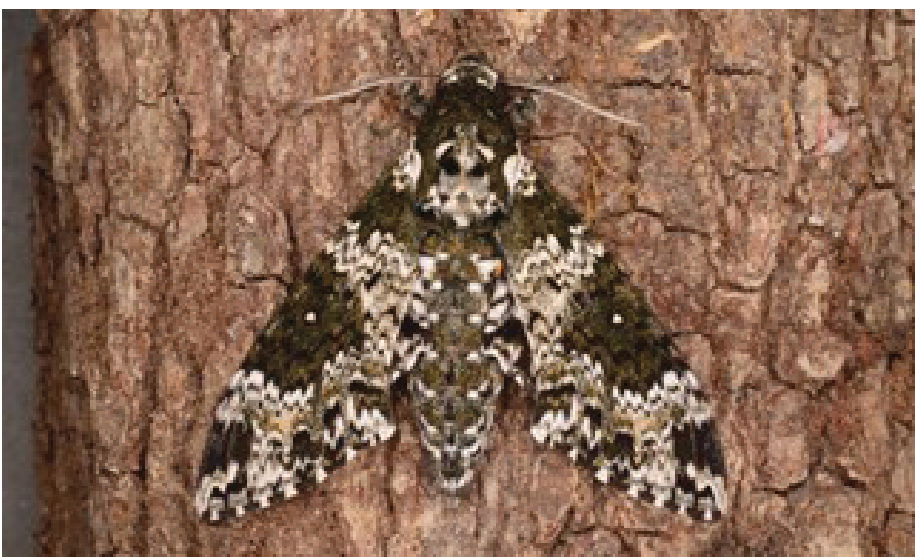

Figure 12. Adult rustic sphinx moth, Manduca rustica, on a tree trunk. Credits: Lyle J. Buss, UF/IFAS

\section{Lichen Management}

Florida residents and visitors can encounter lichens. Lichens grow on fences, window screens, and slowgrowing plants in a landscape or managed grove. Lichen growth may be linked to reduced plant health, not as a cause of plant decline, but rather as an indicator that plants are no longer growing vigorously. Lichen management for aesthetic purposes can be accomplished, but if lichens are on a living plant, their removal could damage the plant and create wound sites where plant pathogens could enter and cause disease symptoms to develop.

\section{Glossary}

- Alga (plural: algae) - a large group of photosynthetic organisms that possess chlorophylls a and $\mathrm{b}$ and store food as starch

- Ascomycetes-a phylum of fungi that reproduces via ascospores produced in asci in cup-shaped ascocarps

- Asexual Reproduction-the process of a living organism producing an exact clone of itself by budding, fracturing or another mechanism
- Cyanobacteria-photosynthetic bacteria that possess chlorophyll a and accessory pigments

- Fungus (plural: fungi) - the kingdom of organisms either single-celled or forming bodies called mycelium composed of tubular strands of hyphae. Fungi reproduce by spores and secrete digestive enzymes and re-absorb nutrients. Those in lichenized relationships parasitize their captive algae/bacteria for nutrition.

- Isidium (plural: isidia) - microscopic, airborne bits of the parent lichen that contain all necessary components to grow a new lichen and are produced as outgrowths of the upper cortex of the thallus and brush off the parent lichen

- Mutualism-two or more organisms living together in a mutually beneficial arrangement

- Mycobiont-in lichen, the fungal component. Provides structure and can absorb rainwater to benefit all components

- Photobiont-in lichen, the organism(s) that provide the fungal host with the sugars that are the by-products of their photosynthetic activity; these may be algae, bacteria, or both

- Soredium (plural: soredia) - microscopic, airborne bits of the parent lichen that contain all necessary components to grow a new lichen, produced inside the thallus and released through openings in the upper cortex

- Thallus-the body of a lichen with fungal hyphae filaments surrounding a layer of photosynthetic organisms

- Yeast-single-celled fungi that exist in a variety of habitats, either individually or in chains, and reproduce by budding

\section{Selected References}

Bates, S. T., G. W. Cropsey, J. G. Caporaso, R. Knight, and N. Fierer. 2011. "Bacterial Communities Associated with the Lichen Symbiosis." Applied and Environmental Microbiology 77 (4): 1309-1314.

Brodo, I. M., S. D. Sharnoff, and S. Sharnoff. 2001. Lichens of North America. Yale University Press.

Byron, M. A., and J. L. Gillett-Kaufman. 2016. "Rustic sphinx, Manduca rustica (Fabricius) (Insecta: Lepidoptera: Sphingidae)." EENY 652. Gainesville: University of Florida Institute of Food and Agricultural Sciences. http://entnemdept.ufl.edu/creatures/ORN/Manduca_rustica.htm 
Honegger, R., and S. Scherrer. 2008. Sexual Reproduction in Lichen-Forming Ascomycetes. Cambridge University Press.

Purvis, W. 2000. Lichens, Smithsonian's Natural World Series. Smithsonian Books.

Ranković, B. R. 2015. Lichen Secondary Metabolites: Bioactive Properties and Pharmaceutical Potential. Springer International Publishing.

Ray, H. A., and J. L. Gillett-Kaufman. 2017. "Grizzled mantid, Gonatista grisea (Fabricius) (Mantodea: Mantidae)." EENY 688. Gainesville: University of Florida Institute of Food and Agricultural Sciences. http://entnemdept.ufl. edu/creatures/misc/grizzled_mantid.html

Richardson, D. H. S. 1992. Pollution Monitoring with Lichens. Pelagic Publishing.

Stephenson, S. L. 2010. The Kingdom Fungi: The Biology of Mushrooms, Molds, and Lichens. Timber Press. 